\title{
THE QUALITY AND AEROBIC STABILITY OF SILAGES FROM A MIXTURE OF LEGUMES WITH GRASSES WITH A CHEMICAL AND MICROBIOLOGICAL ADDITIVES
}

\author{
JAKOŚĆ I TLENOWA TRWAŁOŚĆ KISZONEK Z MIESZANKI \\ ROŚLIN BOBOWATYCH Z TRAWAMI Z DODATKAMI CHEMICZNYM \\ I MIKROBIOLOGICZNYM
}

\author{
Department of Animal Science, UTP University of Science and Technology, Bydgoszcz, Poland
}

\begin{abstract}
Streszczenie. Najlepszym sposobem konserwowania pasz wilgotnych jest ich kiszenie. Jednak niewłaściwie przebiegająca fermentacja może doprowadzić do uzyskania kiszonek złej jakości. Celem badań było określenie wpływu konserwantu chemicznego i dodatku mikrobiologicznego zawierającego bakterie kwasu mlekowego, w tym Lactobacillus buchneri, na skład chemiczny, jakość i tlenową trwałość kiszonek. Materiałem doświadczalnym była podwiędnięta $(302,8 \mathrm{~g}$ suchej masy $\cdot \mathrm{kg}^{-1}$ ) zielonka $\mathrm{z}$ drugiego pokosu mieszanki roślin bobowatych $\mathrm{z}$ trawami w pierwszym roku użytkowania, którą zakiszono w cylindrycznych zbiornikach doświadczalnych z polichlorku winylu (PVC), o pojemności $8654 \mathrm{~cm}^{3}$. Wykonano 3 rodzaje kiszonek (po 4 zbiorniki): kontrolną bez dodatku, $z$ dodatkiem chemicznym i z inokulantem. Konserwant chemiczny składał się z mieszaniny 22,5-27,5\% kwasu mlekowego, 26,2-33,7\% kwasu ortofosforowego, $3,8-5,1 \%$ kwasu mrówkowego, 3,8-5,1\% kwasu propionowego (dozowanie $-6 \mathrm{I} \cdot \mathrm{t}^{-1}$ zielonki). Dodatek mikrobiologiczny zawierał bakterie Enterococcus faecium, Lactobacillus plantarum, Lcb. casei, Lcb. buchneri, Pediococcus pentosaceus w ilości $15 \cdot 10^{9} \mathrm{cfu} \cdot \mathrm{g}^{-1}$ preparatu (dozowanie - $150 \mathrm{~g} \cdot \mathrm{t}^{-1}$ zielonki). Oceniono przydatność zielonki do zakiszania, wykonano analizę składu chemicznego kiszonek i określono ich parametry jakościowe $-\mathrm{pH}, \mathrm{N}-\mathrm{NH}_{3}$ do Nogónego, zawartość kwasów mlekowego, octowego i masłowego. Oceniono także stabilność kiszonek w warunkach tlenowych. Przydatność zielonki do zakiszania była średnia. Kiszonka $z$ dodatkiem chemicznym zawierała więcej suchej masy, kwasu mlekowego i kwasu octowego, a mniej kwasu masłowego i kwaśnego włókna detergentowego (ADF) niż kiszonka kontrolna. Kiszonka z inokulantem zawierała więcej suchej masy, bezazotowych związków wyciągowych (BNW), kwasu mlekowego i kwasu octowego, a mniej tłuszczu i włókna surowego, kwasu masłowego oraz włókna ADF, w porównaniu z kiszonką bez dodatków. Dodatki nie poprawiły tlenowej trwałości kiszonek z mieszanki bobowato-trawiastej.
\end{abstract}

Key words: alfalfa, clover, fescue, Lactobacillus buchneri, timothy, poa.

Słowa kluczowe: koniczyna, kostrzewa, Lactobacillus buchneri, lucerna, tymotka, wiechlina.

\section{INTRODUCTION}

Ensiling is the best way to preserve wet roughage, as it provides the smallest nutrient loss (Weinberg and Muck 1996; Yitbarek and Tamil 2014; Oliveira et al. 2017). However, often the quality of the silage is bad due to an improper fermentation process (Latemae et al. 2004;

Corresponding author - Adres do korespondencji: Piotr Dorszewski, Department of Animal Science, UTP University of Science and Technology, Bydgoszcz, Mazowiecka 28, 85-084 Bydgoszcz, Poland, e-mail: piodor@utp.edu.pl 
Yitbarek and Tamil 2014). One of the ways of controlling fermentation is the use of silage additives (Purwin et al. 2006; Yitbarek and Tamil 2014). These preparations according to the Regulation of the European Parliament and of the Council (2003) fall into Category 1. Technological additives, to the Functional group - Silage additives. By definition, these are "Substances, including enzymes and microorganisms that are introduced into the feed to improve silage production." Due to the way they affect fermentation, silage additives may be its inhibitors or stimulants. Chemical preservatives - e.g. mineral and organic acids and their salts - inhibit the fermentation, while biological additives support it - e.g. inoculants containing lactic acid bacteria, enzymes, molasses (McDonald et al. 1991; Staudacher et al. 1999; Wilkinson 2005; Yitbarek and Tamil 2014).

In Europe and in the United States, the most commonly used additives for ensiling of maize, grass and legumes with a dry matter content of about $300 \mathrm{~g} \cdot \mathrm{kg}^{-1}$ of green forage are bacterial preparations (Yitbarek and Tamil 2014). In silage production, microbial preparations containing lactic acid bacteria are also used in combination with chemical preservatives (Pahlow 2004). The biological part promotes fermentation, while the chemical part is to prevent spoilage of the silage when the silo is opened for feed-out (Pahlow 2004; Wilkinson 2005; Yitbarek and Tamil 2014). Homofermentative lactic acid bacteria are commonly used, but the results of studies on their effect on the quality and stability of silage are different (Wilkinson and Davies 2012; Yitbarek and Tamil 2014). Due to the fact that silage is fed throughout the year, also in the summer when temperatures are high, their aerobic stability is very important (Pahlow and Weißbach 1999). Acetic acid content has a significant influence on it (Oude Elfernik et al. 1999). Among the numerous bacteria producing this acid, silage additives have been used in among all heterofermentative bacterium Lactobacillus buchneri (Pflaum and Gartner 1998; Kung et al. 1999; Oude Elfernik et al. 1999; Yitbarek and Tamil 2014). However, the heterofermentation process less effectively lowers the $\mathrm{pH}$, resulting in greater loss of nutrients under anaerobic conditions (Wilkinson and Davies 2012; Yitbarek and Tamil 2014).

The aim of the study was to determine the effect of chemical preservative and a microbial additive containing lactic acid bacteria, including Lactobacillus buchneri, on the chemical composition, quality and aerobic stability of silages made from wilted green forage from legumes-grasses mixture.

\section{MATERIAL AND METHODS}

The ensiling material was wilted green forage from the second swath of a mixture of legumes with grasses in the first year of use with the following composition: red clover $-32 \%$, alfalfa $-40 \%$, timothy-grass $-12 \%$, red fescue $-12 \%$, smooth meadow-grass $-4 \%$ (the amount of sowing per ha was given in \%). The biomass was mowed with a rotary mower at the beginning of flowering of legumes, before earing of the grasses, wilted out for swath and harvested with a self-propelled forage harvester, chopped at $1.5 \mathrm{~cm}$ theoretical cut and packed in PVC minisilos with a capacity of $8654 \mathrm{~cm}^{3}$ each (diameter $15 \mathrm{~cm}$, height $49 \mathrm{~cm}$ ). Was prepared three variants of silages (in 4 minisilos each): control $(K)$ without additive, with a chemical addition (C) and with a microbiological addition (M). The additives were dispensed to the ensilaged green forage by a hand sprinkler, mixed, and then placed in the minisilos. The biomass was compacted by means of a special hydraulic (press) device with a constant pressure of $6 \cdot 10^{5} \mathrm{~N} \cdot \mathrm{m}^{-2}$. The 
minisilos were sealed tightly with rubber stoppers with fermentation tubes filled with glycerin, allowing the fermentation gasses to escape. They were stored in an air-conditioned room at an ambient temperature of $20 \pm 1^{\circ} \mathrm{C}$. After 6 weeks, the minisilos were opened and silage was removed. From each tank of the given variant, the silage was mixed and samples were taken for analysis. The composition and dosage of additives are given in the Table 1.

Table 1. Components and dosage of silage additives

Tabela 1. Skład i dozowanie dodatków kiszonkarskich

\begin{tabular}{|c|c|c|}
\hline $\begin{array}{l}\text { Additive } \\
\text { Dodatek }\end{array}$ & $\begin{array}{c}\text { Dose } \\
\text { Dozowanie } \\
\end{array}$ & $\begin{array}{c}\text { Components } \\
\text { Skład }\end{array}$ \\
\hline $\mathrm{C}$ & $6 \mathrm{I} \cdot \mathrm{t}^{-1}$ green forage - zielonki & $\begin{array}{l}\text { mixture of: latic acid } 22.5-27.5 \% \text {, ortophosphoric acid } \\
26.2-33.7 \% \text {, formic acid } 3.8-5.1 \% \text {, propionic acid } 3.8-5.1 \% \\
\text { mieszanina kwasów: mlekowego } 22,5-27,5 \% \text {, ortofosforowego } \\
26,2-33,7 \% \text {, mrówkowego } 3,8-5,1 \% \text {, propionowego } 3,8-5,1 \%\end{array}$ \\
\hline$M$ & $150 \mathrm{~g} \cdot \mathrm{t}^{-1}$ green forage - zielonki & $\begin{array}{l}\text { Enterococcus faecium, Lactobacillus plantarum, Lcb. casei, } \\
\text { Lcb. buchneri, Pediococcus pentosaceus, } 15 \cdot 10^{9} \mathrm{cfu} \cdot \mathrm{g}^{-1} \\
\text { preparatu }\end{array}$ \\
\hline
\end{tabular}

The ensilability of green forage was determined on the basis of dry matter content, water soluble carbohydrates (WSC), buffer volume (BF) and fermentation factor (VF) (Weissbach 1992, 1998, Yitbarek and Tamil 2014). The contents of basic nutrients and ADF and neutral detergent fibre (NDF) were determined in silages (AOAC 2012). In addition, the $\mathrm{pH}$ value was determined using the $\mathrm{N}-5178 \mathrm{pH}$-meter. Were determined also lactic acid, acetic acid and butyric acid content (AOAC 2012).

The aerobic stability of silage was tested using a temperature test (Honig 1990; Pahlow and Weissbach 1999). Silage samples were stored in an air-conditioned room at an ambient temperature of $20 \pm 1^{\circ} \mathrm{C}$ in plastic containers placed in polystyrene covers. Silage temperatures during the stability test were detected at 1 hour by the data logger Squirrel 2000 (24 results per day).

The results were statistically processed applying the Statistica software using one-way analysis of variance according to the model: $Y_{\mathrm{ij}}=\mu+a_{\mathrm{i}}+e_{\mathrm{ij}}$, where: $Y-$ value of variable, $\mu$-mean, $a_{i}$ - effect of the group, $e_{i j}$ - experimental error. Significant differences were verified using the least significant difference test. Compatibility of variable distribution with normal distribution was verified with Kolmogorov-Smirnov test, while homogeneity of variance with Brown-Forsythe test.

\section{RESULTS AND DISCUSSION}

The content of water-soluble carbohydrates (WSC) exceeded $80 \mathrm{~g} \cdot \mathrm{kg}^{-1}$ of dry matter and the fermentation factor (VF) was higher than 35 (Table 2). These values indicate that the green forage from a mixture of legumes with grasses was middle to ensiling (McDonald et al. 1991; Weissbach 1992, 1998; Thaysen 2004; Thaysen et al. 2007; Yitbarek and Tamil 2014). However, with such parameters it is purposeful to use silage additives, especially inoculants to accelerate and improve the fermentation (Yitbarek and Tamil 2014). 
Table 2. Ensilability of green forage

Tabela 2. Przydatność zielonki do zakiszania

\begin{tabular}{cccc}
\hline $\begin{array}{c}\mathrm{DM} \\
{\left[\mathrm{g} \cdot \mathrm{kg}^{-1} \mathrm{FM}\right]}\end{array}$ & $\begin{array}{c}\text { WSC } \\
{\left[\mathrm{g} \cdot \mathrm{kg}^{-1} \mathrm{DM}\right]}\end{array}$ & $\mathrm{BC}^{*}$ & $\mathrm{FC}$ \\
\hline 302.80 & 85.20 & 80.00 & 38.80 \\
\hline
\end{tabular}

DM - dry matter - sucha masa, FM - fresh matter - świeża masa, WSC - water-soluble carbohydrates węglowodany rozpuszczalne w wodzie, BC - buffer capacity - pojemność buforowa, FC - fermentation factor współczynnik fermentacji, ${ }^{*} \mathrm{~g}$ lactic acid - kwasu mlekowego $\cdot 100 \mathrm{~g}^{-1} \mathrm{DM}$.

Silage with additives $(C, M)$ contained more $(P \leq 0.01)$ by 5.03 to $5.58 \%$ dry matter compared to the control silage $(\mathrm{K})$ (Table 3$)$. The forage with a chemical additive (C) had a lower $(P \leq 0.01)$ content of ADF than the control silage $(K)$ by almost $8 \%$. A higher NfE content $(P \leq 0.01)$ as recorded in silage with a microbiological additive $(M)$ by almost $7 \%$ in comparison to silage made without additives $(K)$. This feed also contained less $(P \leq 0.01)$ crude fat, crude fibre and ADF than the control silage $(K)$, respectively by $10.76,5.88$ and $4.06 \%$.

Table 3. Chemical composition of silages

Tabela 3. Skład chemiczny kiszonek

\begin{tabular}{lccc}
\hline \multicolumn{1}{c}{ Item } & $\mathrm{K}$ & $\mathrm{C}$ & $\mathrm{M}$ \\
\hline Dry matter - Sucha masa $\left[\mathrm{g} \cdot \mathrm{kg}^{-1} \mathrm{FM}\right]$ & $288.5^{\mathrm{A}} \pm 0.04$ & $303.0^{\mathrm{B}} \pm 0.14$ & $304.6^{\mathrm{B}} \pm 0.11$ \\
Crude ash - Popiół surowy $\left[\mathrm{g} \cdot \mathrm{kg}^{-1} \mathrm{DM}\right]$ & $91.2 \pm 0.21$ & $88.4 \pm 0.31$ & $90.8 \pm 0.28$ \\
Organic matter - Substancja organiczna $\left[\mathrm{g} \cdot \mathrm{kg}^{-1} \mathrm{DM}\right]$ & $908.8 \pm 0.22$ & $911.6 \pm 0.31$ & $909.2 \pm 0.26$ \\
Crude protein - Białko ogólne $\left[\mathrm{g} \cdot \mathrm{kg}^{-1} \mathrm{DM}\right]$ & $160.8 \pm 0.73$ & $157.3 \pm 0.64$ & $153.9 \pm 0.81$ \\
Crude fat - Tłuszcz surowy $\left[\mathrm{g} \cdot \mathrm{kg}^{-1} \mathrm{DM}\right]$ & $35.2^{\mathrm{B}} \pm 0.40$ & $35.9^{\mathrm{B}} \pm 0.25$ & $31.4^{\mathrm{A}} \pm 0.20$ \\
Crude fibre - Włókno surowe $\left[\mathrm{g} \cdot \mathrm{kg}^{-1} \mathrm{DM}\right]$ & $300.8^{\mathrm{B}} \pm 0.26$ & $292.6^{\mathrm{AB}} \pm 0.07$ & $283.1^{\mathrm{A}} \pm 0.40$ \\
$\mathrm{NfE}\left[\mathrm{g} \cdot \mathrm{kg}^{-1} \mathrm{DM}\right]$ & $412.0^{\mathrm{A}} \pm 0.56$ & $425.8^{\mathrm{AB}} \pm 0.81$ & $440.8^{\mathrm{B}} \pm 0.75$ \\
ADF $\left[\mathrm{g} \cdot \mathrm{kg}^{-1} \mathrm{DM}\right]$ & $337.6^{\mathrm{B}} \pm 0.71$ & $310.6^{\mathrm{A}} \pm 0.16$ & $323.9^{\mathrm{AB}} \pm 0.38$ \\
NDF $\left[\mathrm{g} \cdot \mathrm{kg}^{-1} \mathrm{DM}\right]$ & $475.5 \pm 0.28$ & $471.9 \pm 0.32$ & $470.5 \pm 0.37$ \\
\hline
\end{tabular}

$\mathrm{K}$ - control - kontrolna, $\mathrm{C}$ - with chemical additive $-\mathrm{z}$ dodatkiem chemicznym, $\mathrm{M}-$ with microbiological additive $\mathrm{z}$ dodatkiem mikrobiologicznym.

$A B$ - value with differ superscripts differ significantly $(P \leq 0.01)$ - wartości oznaczone różnymi literami różnią się istotnie $(P \leq 0,01)$.

$\mathrm{NfE}$ - N-free extracts - związki bezazotowe wyciągowe, ADF - acid detergent fibre - kwaśne włókno detergentowe, NDF - neutral detergent fibre - neutralne włókno detergentowe.

Other explanations see Table 1 - Pozostałe objaśnienia zob. tab. 1.

A significant increase in dry matter content in temperate climate grass and legume silage were noted for additives containing $\geq 10^{5} \mathrm{cfu}$ of lactic bacteria $\mathrm{g}^{-1}$ of green forage (Oliveira et al. 2017). According to literature, in $35 \%$ of research, inoculation of the ensilaged biomass increased dry matter content compared to the control silage (Yitbarek and Tamil 2014). A similar relationship regarding silage from a mixture of legumes and grasses with an inoculant (M) and a chemical additive (C) was also noted in own research. Limitation of clostridial fermentation, proteolysis and deamination and decarboxylation of amino acids in silages from temperate climate grasses and legumes prepared with an addition of homofermentative and facultative heterofermentative lactic acid bacteria may result in increased dry matter content (Oliveira et al. 2017).

In own studies, the use of silage additives did not affect the crude protein and NDF content. These results are confirmed in literature regarding lactic acid bacteria preparations (Oliveira et al. 2017). 
The $\mathrm{pH}$ value of the silage tested and the ratio of $\mathrm{N}_{-} \mathrm{NH}_{3}$ to $\mathrm{N}_{\text {total }}$ did not differ (Table 4). The most $(P \leq 0.01)$ lactic acid in dry matter was found in silage with a microbiological additive $(M)$ and the least in the control silage $(\mathrm{K})$. This difference amounted to $16.4 \mathrm{~g} \cdot \mathrm{kg}^{-1}$ of dry matter, which constitutes $13.69 \%$. The concentration of acetic acid in silage with additives was significantly higher $(\mathrm{P} \leq 0.01)$ by $1.5(\mathrm{M})$ to $2.4(\mathrm{C}) \mathrm{g} \cdot \mathrm{kg}^{-1}$ of dry matter, that is by $4.62(\mathrm{M})$ to $7.38 \%(\mathrm{C})$ compared to the control silage $(\mathrm{K})$. For one part of acetic acid in silage with a microbiological additive, there was $8 \%$ more lactic acid than in non-additive silage $(\mathrm{K})$, while in chemically preserved biomass $(C)-5.4 \%$ less. The content of butyric acid in experimental variants $(C, M)$ was 21 -times and slightly more than 4-times $(P \leq 0.01)$ less than in the control silage $(\mathrm{K})$. During the exposure of silage to air their temperature did not exceed $23^{\circ} \mathrm{C}$. They were stable for 168 hours of the test.

Table 4. Quality and aerobic stability of silages

Tabela 4. Jakość i stabilność tlenowa kiszonek

\begin{tabular}{lccc}
\hline \multicolumn{1}{c}{ Item } & Wyszczególnienie & $\mathrm{K}$ & $\mathrm{M}$ \\
\hline $\mathrm{pH}$ & $4.37 \pm 0.10$ & $4.40 \pm 0.60$ & $4.42 \pm 0.16$ \\
$\mathrm{~N}-\mathrm{NH}_{3}$ to $\mathrm{N}_{\text {total }}-\mathrm{N}-\mathrm{NH}_{3}$ do $\mathrm{N}_{\text {ogólnego }}$ & $9.27 \pm 0.89$ & $8.44 \pm 0.45$ & $9.25 \pm 1.02$ \\
Lactic acid - Kwas mlekowy & $119.8^{\mathrm{A}} \pm 1.2$ & $123.4^{\mathrm{B}} \pm 1.9$ & $136.2^{\mathrm{C}} \pm 1.5^{-9}$ \\
Acetic acid - Kwas octowy & $32.5^{\mathrm{A}} \pm 0.8$ & $34.9^{\mathrm{B}} \pm 0.9$ & $34.0^{\mathrm{B}} \pm 0.8$ \\
Lactic acid : acetic acid - Kwas mlekowy : kwas octowy & $3.7: 1$ & $3.5: 1$ & $4.0: 1$ \\
Butyric acid - Kwas masłowy & $2.1^{\mathrm{B}} \pm 0.05$ & $0.1^{\mathrm{A}} \pm 0.01$ & $0.5^{\mathrm{A}} \pm 0.02$ \\
Aerobic stability - Stabilność tlenowa [h] & 168 & 168 & 168 \\
\hline
\end{tabular}

Explanations see Table 3 - Objaśnienia zob. tab. 3.

The results of the study presented in literature indicate that silage containing lactic acid bacteria had lower $\mathrm{pH}$, contained less acetic acid and butyric acid and ammonia nitrogen, and more lactic acid. In over $60 \%$ of the study, the inoculation of the ensiled biomass in comparison to the control silage resulted in lowering $\mathrm{pH}$, improved the lactic acid to acetic acid ratio and lowered ammonia nitrogen content (Yitbarek and Tamil 2014). Reducing the content of butyric acid and ammonia nitrogen is probably the result of limiting clostridial fermentation (Oliveira et al. 2017). In own studies, the chemical (C) and microbiological (M) additives had no effect on the $\mathrm{pH}$ and ammonia nitrogen content. On the other hand, it was noted that silage was an inoculant (M) with lactic acid fermentation bacteria and with Lactobacillus buchneri contained more lactic acid than silage without additive $(K)$ and with a chemical preservative $(C)$ and more acetic acid than the control variant $(\mathrm{K})$. This was reflected in the wider proportion of both of these acids in this silage. Ensilaged biomass with a chemical additive $(C)$ and an inoculant $(M)$ contained less butyric acid than that ensilaged without additive $(\mathrm{K})$.

In silages with a dry matter content of 300 to $450 \mathrm{~g}$, the $\mathrm{pH}$ should amount to $\leq 4.5$, the acetic acid and butyric acid content should not exceed 30 and $3 \mathrm{~g}$ in dry matter respectively (Wilkinson 2005). Our own results indicate that the analysed silages had a pH and butyric acid content at an appropriate level. Content of acetic acid in the amount of only more by about $2.5(\mathrm{~K})$ to 4.9 (C) $\mathrm{g} \cdot \mathrm{kg}^{-1}$ dry matter was noted in comparison with the literature data (Staudacher and Schenkel 2007). 
One of the most important criteria for the evaluation of silage is their aerobic stability (Pahlow and Weissbach 1999). It specifies the number of days during which in the silage exposed to air at a temperature of $20^{\circ} \mathrm{C}$, its temperature will not exceed $3^{\circ} \mathrm{C}$ above ambient temperature. The value of $3^{\circ} \mathrm{C}$ is determined as the limit of stability. Some research results indicate that inoculants with Lactobacillus buchneri improved aerobic stability of silage (Kung et al. 1999; Oude-Elfernik et al. 1999). In own studies, silage did not heat up above $23^{\circ} \mathrm{C}$ for 168 hours of the stability test. The additives used did not improve the aerobic stability of silage from the mixture of legumes with grasses. Some research results indicate that the Lactobacillus buchneri do not improve the aerobic stability of silage (Oliveira et al. 2014).

\section{CONCLUSIONS}

The ensilability of green forage from a mixture of legumes with grasses was middle. The applied additives influenced changes in the content of some nutrients and silage acids as compared to their contents in the control silage $(\mathrm{K})$. The chemical additive $(\mathrm{C})$ increased the content of dry matter, lactic acid and acetic acid, and reduced the content of ADF and butyric acid $(P \leq 0.01)$. The microbiological additive $(M)$ increased the content of dry matter, NfE, lactic acid and acetic acid, and decreased $(P \leq 0.01)$ crude fat and crude fibre, butyric acid and ADF.

Silage exposed to air did not heat up over $23^{\circ} \mathrm{C}$ within 7 days of the test - all were stable. Additives did not improve the aerobic stability of silage from a mixture of legumes with grasses.

\section{REFERENCES}

AOAC. 2012. Official methods of analysis. 19th ed. Gaithersburg, USA, Association of Official Analytical Chemists.

Honig H. 1990. Evaluation of aerobic stability. Grov. Grass Forage Rep. Uppsala, Sweden 3 (spec. issue), 76-82.

Kung L.Jr., Ranjit N.K., Robinson J.M., Charley R.C. 1999. Inoculation with Lactobacillus buchneri improves the aerobic stability of barley silage, in: Conference Proceedings. The XIlth International Silage Conference, Upsalla, Sweden, July 5-7, 1999. Upsalla, Swedish University of Agricultural Sciences, 272-273.

Läättemäe P., Lääts A., Tamm U. 2004. The technological factors affecting the quality of big bale silage, in: 20th General Meeting, Land use systems in grassland dominated regions. Eds. A. Lüscher, B. Jeangros, W. Kessler, O. Huguenin, M. Lobsiger, N. Millar, D. Suter, Grassland Science in Europe 9, 987-989.

McDonald P., Henderson A.R., Heron S.J.E. 1991. The biochemistry of silage. 2nd ed. Chalcombe Publications, Marlow, Bucks.

McEniry J., O'Kiely P., Clipson N.J.W., Forristal P.D., Doyle E.M. 2006. The microbiological and chemical composition of baled and precision-chop silages on a sample of farms in County Meath. Irish J. Agric. Food Res. 45, 73-83.

Oliveira A.S., Weinberg Z.G., Ogunade I.M., Cervantes A.A.P., Arriola K.G., Jiang Y., Kim D., Li X., Gonçalves M.C.M., Vyas D., Adesogan A.T. 2017. Meta-analysis of effects of inoculation with homofermentative and facultative heterofermentative lactic acid bacteria on silage fermentation, aerobic stability, and the performance of dairy cows. J. Dairy Sci. 100, 4587-4603, https://doi.org/10.3168/jds.2016-11815. 
Oude Elfernik S.J.W.H., Dreihuis F., Krooneman J., Gottschal J.C., Sierk F. 1999. Lactobacillus buchneri can improve the aerobic stability of silage via a novel fermentation pathway: the anaerobic degradation of lactic acid to acetic acid and 1,2 - propanediol, in: Conference Proceedings. The XIIth International Silage Conference, Upsalla, Sweden, July 5-7, 1999. Upsalla, Swedish University of Agricultural Sciences, 266-267.

Pahlow G. 2004. Erfahrungen mit Mikroorganismen in der Silierung. 20. Hülsenberger Gespräche Mikrobiologe und Tierernährung. Lübeck, Aus der Schriftenreihe der H. Wilhelm Schaumann Stiftung, 85-93.

Pahlow G., Weissbach F. 1999. New aspects of evaluation and application of silage additives. Landbauforsch, Völkenrode SH 206, 141-158.

Purwin C., Łaniewska-Trokenheim Ł., Warmińska-Radyko I., Tywończuk J. 2006. Jakość kiszonek aspekty mikrobiologiczne, zdrowotne i produkcyjne [Silage quality: microbiological, health-promoting and production aspects]. Med. Weter. 62, 865-869. [in Polish]

Staudacher W., Pahlow G., Honig H. 1999. Certification of silage additives in Germany by DLG. Conference Proceedings, The XIlth International Silage Conference, July 5-7, Upsalla, Sweden, Upsalla, Swedish University of Agricultural Sciences, 239-240.

Staudacher W., Schenkel H. 2007. Analytische Kenngrössen und Bewärtung der Gärqualität von Silagen unter besonderer Berücksichtigung des DLG-Schlüssels [Analytical parameters to characterize the quality of the fermentation process and of the silage with special emphasis on the DLG-score]. Übers. Tierernährg. 35, 45-53. [in German]

Thaysen J. 2004. Die Produktion von qualitativ hochwertigen Grassilagen [Production of high-quality grass silages. Übers. Tierernährg]. 32, 57-102. [in German]

Thaysen J., Honig H., Kalzendorf Ch., Spiekers H., Staudacher W. 2007. Siliermittel: rechtliche Rahmenbedingungen, Wirksamkeit DLG-geprüfter Produkte und Einsatzempfehlungen [Silage additives: Aspects of feed legislation, efficacy of DLG-approved products and recommendations for application]. Übers. Tierernährg. 35, 55-91. [in German]

Weinberg Z.G., Muck R.E. 1996. New trends and opportunities in the development and use of inoculants for silage. FEMS Microbiol. Rev. 19, 53-68.

Weissbach F. 1992. Bestimmung der Pufferkapazität. Braunsschweig, Institut für Grünland- und Futterpflanzenforschung FAL, 3. [in German]

Weissbach F.1998. Über der Einfluss von verschiedenen Kräutern in Aufwuchs extensive genutzter Wiesen auf den Gärungsverlauf bei Bereitung von Grassilage [The influence of different herbs in the growth of extensive meadows on the fermentation during preparation of grass silage]. Zesz. Probl. Post. Nauk Rol. 462, 297-313. [in German]

Wilkinson J.M. 2005. Silage. Lincoln, Chalcombe Publications.

Wilkinson J.M., Davies D.R. 2012. The aerobic stability of silage: key findings and recent development. Grass Forage Sci. 68, 1-19.

Yitbarek M.B., Tamir B. 2014. Silage additives. Review. Open J. Appl. Sci. 4, 258-274. http://dx.doi.org/ /10.4236/ojapps.2014.45026.

\begin{abstract}
The best way of preserving wet roughage is ensiling. However, fermentation which is performed improperly can lead to obtaining poor quality silage. The aim of the study was to determine the effect of a chemical preservative and a microbial additive containing lactic acid bacteria, including Lactobacillus buchneri, on the chemical composition, quality and aerobic stability of silages. The experimental material was wilted $\left(302.8 \mathrm{~g}\right.$ dry matter $\left.\cdot \mathrm{kg}^{-1}\right)$ green forage from the second swath of a mixture of legumes with grasses in the first year of use which was ensiled in cylindrical experimental polyvinyl chloride (PVC) minisilos with a capacity of $8654 \mathrm{~cm}^{3}$. Three types of silage (in 4 minisilos each) were made: control without additive, with a chemical additive and with an inoculant. The chemical preservative consisted of a mixture of acids: $22.5-27.5 \%$ lactic acid; $26.2-33.7 \%$ phosphoric acid; $3.8-5.1 \%$ formic acid; $3.8-5.1 \%$ propionic acid - dosage $6 \mathrm{I} \cdot \mathrm{t}^{-1}$ of green forage. The Enterococcus faecium, Lactobacillus plantarum,
\end{abstract}


Lcb. casei, Lcb. buchneri, Pediococcus pentosaceus bacteria contained a microbiological additive in the amount of $15 \cdot 10^{9} \mathrm{cfu} \cdot \mathrm{g}^{-1}$ of the preparation - dosage $150 \mathrm{~g} \cdot \mathrm{t}^{-1}$ of green forage. The ensilability of green forage was evaluated, a chemical composition analysis of silage was performed and their qualitative parameters were determined $-\mathrm{pH}, \mathrm{N}-\mathrm{NH}_{3}$ to $\mathrm{N}_{\text {total }}$, content of lactic acid, acetic acid and butyric acids was determined. The stability of silage under aerobic conditions was also evaluated. The ensilability of the green forage was middle. The silage with a chemical additive contained more dry matter, lactic acid and acetic acid, and less acid detergent fibre (ADF) than the control silage. The silage with the inoculant contained more dry matter, nitrogen-free extracts (NfE), lactic acid and acetic acid, and less crude fat and crude fibre, butyric acid and ADF compared to the silage without additives. The additives did not improve the aerobic stability of silage from the legume-grass mixture. 